\title{
Enhancing Organisation Performance for Customer Satisfaction and Cost Effectiveness through Integrated Management System
}

\author{
Sendil Mourougan ${ }^{1}$, Dr. K. Sethuraman ${ }^{2}$ \\ ${ }^{1}$ (Business Administration, Annamalai University, India) \\ ${ }^{2}$ (Business Administration, Annamalai University, India)
}

\begin{abstract}
An integrated management system results when an organization uses one single management system to manage multiple aspects of organizational performance. This paper discusses about the various management systems that can be integrated. It also explains about the management system and its corresponding ISO standard. It details about the management standards approach and structure, its benefits and compatibility with other standards.
\end{abstract}

Keywords: Ims, Iso, Pdca, Qms, Ems, Ohsms, Csr, Cms, Isms, Enms, Bcms, Isms, Esms, Scsms, Fsms, Kpi, Risk Management, Itsm.

\section{Introduction}

Integrated management system combines all related components of a business into one system for easier management and operations. On the part of the different structure of ISO standards, it is difficult to integrate the management systems into integrated management system. This is the reason why International Organization for Standardization published Annex SL. According to this Annex SL, the new published standards will have the common High-level structure (HLS).

\section{Integrated Management System (IMS)}

An Integrated Management System (IMS) integrates all of an organization's systems and processes into one complete framework, enabling an organization to work as a single unit with unified objectives to achieve its purpose and mission. Organizations often focus on management systems individually, often in silos and sometimes even in conflict. The integration of all the management systems into a single system and centrally managed is defined as Integrated Management System. The benefits of an Integrated Management System are:

- Meet all standard requirements with one set of policies and procedures.

- Audit more than one system at a time to save money and resources.

- Improve overall efficiency by removing the need to duplicate tasks.

- Clearly defined roles and responsibilities highlight common objectives.

- Make it easier to continually improve all the management systems.

\section{International Organization For Standardization}

ISO (International Organization for Standardization) has a membership of 164 national standards bodies from countries large and small, industrialized, developing and in transition, in all regions of the world. ISO's portfolio of over 19200 standards provides business, government and society with practical tools for all three dimensions of sustainable development: economic, environmental and social. ISO standards make a positive contribution to the world. They facilitate trade, spread knowledge, disseminate innovative advances in technology, and share good management and conformity assessment practices.

\subsection{ISO standard}

ISO standards provide solutions and achieve benefits for almost all sectors of activity, including agriculture, construction, mechanical engineering, manufacturing, distribution, transport, healthcare, information and communication technologies, the environment, energy, safety and security, quality management, and services. ISO only develops standards for which there is a clear market requirement. The work is carried out by experts in the subject drawn directly from the industrial, technical and business sectors that have identified the need for the standard, and which subsequently put the standard to use. These experts may be joined by others with relevant knowledge, such as representatives of government agencies, testing laboratories, consumer associations and academia, and by international governmental and nongovernmental organizations. 


\subsection{Development of ISO standards}

The development of new ISO standard has several steps. New standard is proposed to relevant technical committee. If proposal is accepted, then working group (WG) of experts start discussion to prepare a working draft. The 1st committee draft is registered and distributed for comments and recommendations by the ISO Central Secretariat. The consensus for the technical content is reached if successive committee draft is presented and finally the text is finalized as DIS (Draft International Standard) for submission. Within period of five months, DIS is circulated among all ISO members for comment and approval. Once the draft is approved, it becomes FDIS (Final Draft International Standard). Again, if the consensus is reached, then the final draft is sent to all ISO members. After the approval by member vote, ISO standard is published.

\subsection{High-level Structure}

International Organization for Standardization (ISO) has more than 280 technical committees that are made up of representatives of industry, non-governmental organizations (NGOs), governments and other stakeholders. They deal with different subjects. ISO developed ISO Guide 83 that was accepted and published as Annex SL. The effort to uniform the all standards of manager systems and create the united structure of standards is the reason why Annex SL was published. All standards of management systems will have the same High level structure (HLS) by this Annex SL, the following 10 clauses: 1 - Scope, 2 - Normative references, 3 - Terms and definitions, 4 - Context of the organization, 5 - Leadership, 6 - Planning, 7 - Support, 8 - Operation, 9 - Performance evaluation, 10 - Improvement.

\subsection{Process approach}

This International Standard adopts a process approach for establishing, implementing, operating, monitoring, reviewing, maintaining and improving an organization's process. An organization needs to identify and manage many activities in order to function effectively. Any activity using resources and managed in order to enable the transformation of inputs into outputs can be considered to be a process. Often the output from one process directly forms the input to the next process.

The application of a system of processes within an organization, together with the identification and interactions of these processes, and their management, can be referred to as a "process approach". PDCA (plando-check-act or plan-do-check-adjust) is an iterative four-step management method used in business for the control and continuous improvement of processes and products. It is also known as the Deming circle/cycle/wheel, Shewhart cycle, control circle/cycle, or plan-do-study-act (PDSA). Another version of this PDCA cycle is OPDCA. The added "O" stands for observation or as some versions say "Grasp the current condition." This emphasis on observation and current condition has currency with Lean manufacturing/Toyota Production System literature.

- PLAN: Establish the objectives and processes necessary to deliver results in accordance with the expected output (the target or goals).

- DO: Implement the plan, execute the process, and make the product. Collect data for charting and analysis in the following "CHECK" and "ACT" steps.

- CHECK: Study the actual results (measured and collected in "DO" above) and compare against the expected results (targets or goals from the "PLAN") to ascertain any differences.

- ACT: If the CHECK shows that the PLAN that was implemented in DO is an improvement to the prior standard (baseline), then that becomes the new standard (baseline) for how the organization should ACT going forward (new standards are enACTed). If the CHECK shows that the PLAN that was implemented in $\mathrm{DO}$ is not an improvement, then the existing standard (baseline) will remain in place.

\subsection{Quality Management System}

\section{Quality Management System(QMS)}

A Quality Management System (QMS) is a collection of business processes focused on achieving quality policy and quality objectives to meet customer requirements. It is expressed as the organizational structure, policies, procedures, processes and resources needed to implement quality management. Improving the organization's QMS can positively boost the profitability. Demonstrating real commitment to product and service quality can transform the corporate culture because, employees understand the requirement for ongoing improvement. ISO 9000 standard provides the framework for organisations to implement QMS.

\subsection{ISO 9001}

The ISO 9000 series are based on eight quality management principles. (1) Customer focus (2) Leadership (3) Involvement of people (4) Process approach (5) System approach to management (6) Continual Improvement (7) Factual approach to decision making and (8) Mutually beneficial supplier relationships. 
- $\quad$ ISO 9001 Quality Management Systems

- AS9100 Aerospace and Defense

- $\quad$ ISO 13485 Medical Devices

- TS 16949 Automotive

ISO 9001: 2015 adopts PDCA process approach and is compatible with ISO 14001

\subsection{Benefits}

It brings (a) quality and continuous improvement together to align with the business strategies of the organization, (b) greater involvement in the management system by the leadership team ensures the whole organization to get motivated towards the organizations goals and objectives, (c) reinforces the use of the management system as a governance toll to identify business opportunities that contribute to bottom line improvements. With the new structure applicable to all new ISO management systems standards it will be much easier to implement multiple, integrated management systems.

\subsection{ISO 9001:2015 structure}

\begin{tabular}{|c|c|c|}
\hline Clause title & Clause $^{\circ}$ & Description of clause contents \\
\hline Introduction & Clause 0 & Explains about the purpose of ISO 9001. \\
\hline Scope & Clause 1 & Defines the scope of ISO 9001 and identifies certain limitations and \\
\hline $\begin{array}{l}\text { Normative } \\
\text { references }\end{array}$ & Clause 2 & Refers to other publications that provide information or guidance. \\
\hline $\begin{array}{l}\text { Terms and } \\
\text { definitions }\end{array}$ & Clause 3 & $\begin{array}{l}\text { Identifies and provides the definition of key terms that are of fundamental } \\
\text { importance for QMS and for using ISO } 9001 \text {. }\end{array}$ \\
\hline $\begin{array}{l}\text { Context of the } \\
\text { organisation }\end{array}$ & Clause 4 & $\begin{array}{l}\text { Clause } 4 \text { also looks at process management and organizations need to } \\
\text { determine process risk and have measures in place to ensure effective } \\
\text { operation. They'll also need to allocate responsibilities for particular } \\
\text { processes or sets of processes. }\end{array}$ \\
\hline Leadership & Clause 5 & $\begin{array}{l}\text { This requirement has been set in place to ensure quality policies are aligned } \\
\text { with strategic direction. This will help organizations to identify, assess and } \\
\text { manage all risks that could stand in the way of meeting product requirements. } \\
\text { Clause } 5 \text { also highlights the need to allocate responsibility for process } \\
\text { management. }\end{array}$ \\
\hline Planning & Clause 6 & $\begin{array}{l}\text { This section will focus the need for preventive action and focus on risk and } \\
\text { opportunities that relate to product conformity and customer satisfaction. } \\
\text { Clause } 6 \text { also sets out better requirements to help organizations manage }\end{array}$ \\
\hline Support & Clause 7 & $\begin{array}{l}\text { Clause } 7 \text { looks at how to manage changes to resources more effectively. It } \\
\text { also includes a new requirement to determine, present and maintain } \\
\text { knowledge to continuously meet customer needs and improve their overall } \\
\text { satisfaction. The third change to Clause } 7 \text { refers to the competence } \\
\text { requirements that relate to every process or set of processes within } \\
\text { organizations. }\end{array}$ \\
\hline Operation & Clause 8 & $\begin{array}{l}\text { Clause } 8 \text { has two new requirements. The first is contingency planning to } \\
\text { improve customer communication, while the second looks at ways to assess } \\
\text { the suitability of a design before it reaches operations. Clause } 8 \text { also specifies } \\
\text { the importance of controlling all outsourced activities through efficient risk } \\
\text { management. }\end{array}$ \\
\hline $\begin{array}{l}\text { Performance } \\
\text { Evaluation }\end{array}$ & Clause 9 & $\begin{array}{l}\text { Clause } 9 \text { includes stronger monitoring and measurement requirements and } \\
\text { also introduces how this works in relation to risk and the effectiveness of an }\end{array}$ \\
\hline Improvement & Clause 10 & Clause 10 sets out a more structured approach for Continual Improvement \\
\hline
\end{tabular}

\subsection{Environmental Management System}

\section{Environmental Management System (EMS)}

An Environmental Management System (EMS) is a set of processes and practices that enable an organization to reduce its environmental impacts and increase its operating efficiency. It is a systemic approach to handling environmental issues within an organization. It includes the organizational structure, planning and resources for developing, implementing and maintaining policy for environmental protection. ISO 14000 standards provide a guideline or framework for organizations to systematize and improve their environmental management efforts.

\subsection{ISO 14001}

The ISO 14001 standard is the most important standard within the ISO 14000 series. ISO 14001 specifies the requirements of an Environmental Management System (EMS) for small to large organizations. Other standards in the series are actually guidelines, many help to achieve registration to ISO 14001. This standard is built on PDCA process approach and is compatible with ISO 9001:2015, ISO 27001:2013 and the forthcoming ISO 45001:2016. 


\subsection{Benefits}

ISO 14001:2015 will help organizations to put a policy in place that promotes environmental protection specific to the context of their business. This will strengthen their commitment to sustainable development and resource use, climate change and the protection of ecosystems.

ISO 14001:2015 structure

\begin{tabular}{|c|c|c|}
\hline Clause title & Clause & Description of clause contents \\
\hline Introduction & Clause 0 & Explains about the purpose of ISO 14001. \\
\hline Scope & Clause 1 & $\begin{array}{l}\text { Defines the scope of ISO } 14001 \text { and identifies certain limitations and } \\
\text { exclusions. }\end{array}$ \\
\hline Normative references & Clause 2 & Refers to other publications that provide information or guidance. \\
\hline Terms and definitions & Clause 3 & $\begin{array}{l}\text { Identifies and provides the definition of key terms that are of } \\
\text { fundamental importance for EMS and for using ISO } 14001 \text {. }\end{array}$ \\
\hline $\begin{array}{l}\text { Context of the } \\
\text { organisation }\end{array}$ & Clause 4 & $\begin{array}{l}\text { This is an entirely new clause that brings a better and more strategic } \\
\text { understanding of all the factors affecting the way organizations manage } \\
\text { their environmental responsibilities. Some examples are the climate, } \\
\text { resource availability and social, regulatory, financial and technology } \\
\text { changes. }\end{array}$ \\
\hline Leadership & Clause 5 & $\begin{array}{l}\text { This has been enhanced to ensure more commitment, responsiveness, } \\
\text { active support and feedback from the organization's top management. } \\
\text { Their buy-in is critical for the success of the environmental management } \\
\text { system, so they'll be directly or indirectly tasked with specific } \\
\text { responsibilities. These changes will help to raise the profile of an } \\
\text { environmental management system, making sure top management looks } \\
\text { at it from a strategic, tactical or operational level. }\end{array}$ \\
\hline Planning & Clause 6 & $\begin{array}{l}\text { This clause will specifically focus on heightened awareness and } \\
\text { competence. }\end{array}$ \\
\hline Support & Clause 7 & $\begin{array}{l}\text { This clause will be more prescriptive to encourage consistency across } \\
\text { the organization. One example is communication requirements. This } \\
\text { makes all communication more transparent, appropriate, credible and } \\
\text { reliable. The clause separates internal and external communication and } \\
\text { requires more detail when reporting externally. }\end{array}$ \\
\hline Operation & Clause 8 & $\begin{array}{l}\text { It now places greater emphasis on the concept of the 'value chain' that } \\
\text { impacts the environmental management system. It also looks at how } \\
\text { organizations control changes and outsource specific processes. }\end{array}$ \\
\hline $\begin{array}{l}\text { Performance } \\
\text { Evaluation }\end{array}$ & Clause 9 & $\begin{array}{l}\text { This is a new clause that has pulled together a number of existing } \\
\text { clauses from the current version including monitoring and measurement } \\
\text { and management review. This will help companies to gather the right } \\
\text { records and prove that their environmental management system meets } \\
\text { their business objectives. }\end{array}$ \\
\hline Improvement & Clause 10 & $\begin{array}{l}\text { Although it retains the principle of the current non-conformity and } \\
\text { corrective action clause, the new standard is more detailed in its } \\
\text { consideration of nonconformity and resulting action needed. }\end{array}$ \\
\hline
\end{tabular}

VI. Occupational Health and Safety Management Systems (OHSMS)

\subsection{Occupational Health and Safety Management Systems}

Occupational Safety and Health (OSH) also commonly referred to as Occupational Health and Safety (OHS) or Workplace Health and Safety (WHS) is an area concerned with the safety, health and welfare of people engaged in work or employment. The goals of occupational safety and health programs include fostering a safe and healthy work environment. OSH may also protect co-workers, family members, employers, customers, and many others who might be affected by the workplace environment.

\subsection{ISO 45001}

OHSAS 18001 sets out the minimum requirements for occupational health and safety management best practice. ISO is developing an occupational health and safety (OH\&S) management system standard (ISO 45001) which is intended to enable organizations to manage their OH\&S risks and improve their OH\&S performance. ISO 45001 is intended to be applicable to any organization regardless of its size, type and nature. ISO 45001 enables an organization, through its $\mathrm{OH} \& \mathrm{~S}$ management system, to integrate other aspects of $\mathrm{H} \& \mathrm{~S}$. OHSAS Standard is based on PDCA process approach and is compatible with ISO 9001 and ISO 14001.

\subsection{Benefits}

An ISO 45001 enables an organization to improve its OH\&S performance by: (a) improving its ability to respond to regulatory compliance issues, (b) reducing the overall costs of incidents, (c) reducing downtime and the costs of disruption to operations, (d) reducing the cost of insurance premiums, (e) reducing absenteeism and employee turnover rates, (f) recognition for having achieved an international benchmark (which may in turn influence customers who are concerned about their social responsibilities). 


\begin{tabular}{|c|c|c|}
\hline Clause title & Clause $\mathbf{n}^{\circ}$ & Description of clause contents \\
\hline Scope & Clause 1 & $\begin{array}{l}\text { Defines the scope of OHSAS 18001and identifies certain limitations } \\
\text { and exclusions. }\end{array}$ \\
\hline Reference publications & Clause 2 & Refers to other publications that provide information or guidance. \\
\hline Terms and definitions & Clause 3 & $\begin{array}{l}\text { Identifies and provides the definition of key terms that are of } \\
\text { fundamental importance for understanding and using OHSAS } 18001 \text {. }\end{array}$ \\
\hline $\begin{array}{l}\text { Context of the } \\
\text { organisation. }\end{array}$ & Clause 4 & $\begin{array}{l}\text { This clause includes the general requirements from OHSAS } 18001 \\
\text { but has two new sub-clauses } 4.1 \text { Understanding the organization and } \\
\text { its context and } 4.2 \text { Understanding the needs and expectations of } \\
\text { interested parties. It also includes determining the scope of the } \\
\text { OHSMS and defines OHSMS. }\end{array}$ \\
\hline Leadership & Clause 5 & $\begin{array}{l}\text { It includes Leadership and commitment, policy and organisation } \\
\text { roles, responsibilities and authorities. }\end{array}$ \\
\hline Planning & Clause 6 & $\begin{array}{l}\text { This clause covers the OHSAS } 18001 \text { Planning requirements with } \\
\text { two main changes. First, actions to address risks and opportunities } \\
\text { requires organisations to take into account not just OH\&S hazards, } \\
\text { but also the sub-clauses mentioned under } 4 \text { above, namely } 4.1 \\
\text { Understanding the organisation and its context and } 4.2 \text { Understanding } \\
\text { the needs and expectations of interested parties. Second, sub-clause } \\
6.2 \text { is concerned with 'OH\&S objectives and planning to achieve } \\
\text { them. }\end{array}$ \\
\hline Support & Clause 7 & $\begin{array}{l}\text { The OHSAS resources, competence, awareness and communication } \\
\text { requirements are covered here and so are the requirements with regard } \\
\text { to documents and records. }\end{array}$ \\
\hline Operations & Clause 8 & $\begin{array}{l}\text { This clause covers the OHSAS } 18001 \text { requirements for Operational } \\
\text { control and Emergency preparedness and response in a structured } \\
\text { manner. There are additional requirements in ISO } 45001 \text { dealing with } \\
8.3 \text { Outsourcing, } 8.4 \text { Procurement and } 8.5 \text { Contractors. }\end{array}$ \\
\hline Performance evaluation & Clause 9 & $\begin{array}{l}\text { This is a wide-ranging clause that takes in the OHSAS } 18001 \\
\text { requirements for Performance measurement and monitoring, Internal } \\
\text { audit and Management review. }\end{array}$ \\
\hline Improvement & Clause 10 & $\begin{array}{l}\text { This clause consists of two sub-clauses } 10.1 \text { Incident, nonconformity } \\
\text { and corrective action and } 10.2 \text { Continual improvement }\end{array}$ \\
\hline
\end{tabular}

\section{Corporate Social Responsibility and Guidance on Social Responsibility}

\subsection{Corporate Social Responsibility}

Organizations around the world, and their stakeholders, are becoming increasingly aware of the need for and benefits of socially responsible behaviour. An organization's performance in relation to the society in which it operates and to its impacts on the environment has become a critical part of measuring its overall performance and its ability to continue operating effectively. The objective of social responsibility is to contribute to sustainable development.

\subsection{ISO 26000}

ISO 26000:2011 is intended to assist organizations in contributing to sustainable development. and defines seven principles of social responsibility: (1) Accountability, (2) Transparency, (3) Ethical behavior, (4) Respect for stakeholder interest, (5) Respect for rule of law (6) Respect for international norms of behavior and (7) Respect for human rights. ISO 26000 adapts PDCA process approach and is compatible with ISO 14001 or OHSAS 18001.

\subsection{Benefits}

An organization performance on social responsibility brings (a) Competitive advantage, (b) Reputation, (c) the ability to attract and retain workers or members, customers, clients and users, (d) Maintenance of employee morale, commitment and productivity, (e) Perception of investors, owners, donors, sponsors and the financial community, (f) relationships with companies, governments, the media, suppliers, peers, customers .

\subsection{ISO 26000:2011 structure}

\begin{tabular}{|l|l|l|}
\hline \multicolumn{1}{|c|}{ Clause title } & Clause $\mathbf{n}^{\circ}$ & \multicolumn{1}{c|}{ Description of clause contents } \\
\hline Scope & Clause 1 & $\begin{array}{l}\text { Defines the scope of ISO 26000 and identifies certain limitations } \\
\text { and exclusions. }\end{array}$ \\
\hline Terms and definitions & Clause 2 & $\begin{array}{l}\text { Identifies and provides the definition of key terms that are of } \\
\text { fundamental importance for understanding social responsibility } \\
\text { and for using ISO 26000. }\end{array}$ \\
\hline $\begin{array}{l}\text { Understanding } \\
\text { social responsibility }\end{array}$ & Clause 3 & $\begin{array}{l}\text { Describes the important factors and conditions that have } \\
\text { influenced the development of social responsibility and that } \\
\text { continue to affect its nature and practice. The clause includes } \\
\text { guidance for small and medium-sized organizations on the use of }\end{array}$ \\
\hline
\end{tabular}




\begin{tabular}{|c|c|c|}
\hline & & ISO 26000. \\
\hline $\begin{array}{l}\text { Principles of } \\
\text { social responsibility }\end{array}$ & Clause 4 & Introduces and explains the principles of social responsibility. \\
\hline $\begin{array}{l}\text { Recognizing social } \\
\text { responsibility and } \\
\text { engaging stakeholders }\end{array}$ & Clause 5 & $\begin{array}{l}\text { Addresses two practices of social responsibility: an organization's } \\
\text { recognition of its social responsibility, and its identification of, } \\
\text { and engagement with, its stakeholders. It provides guidance on the } \\
\text { relationship between an organization, its stakeholders and society, } \\
\text { on recognizing the core subjects and issues of social } \\
\text { responsibility, and on an organization's sphere of influence. }\end{array}$ \\
\hline $\begin{array}{l}\text { Guidance on social } \\
\text { responsibility } \\
\text { core subjects }\end{array}$ & Clause 6 & $\begin{array}{l}\text { Explains the core subjects and associated issues relating to social } \\
\text { responsibility. For each core subject, information has been } \\
\text { provided on its scope, its relationship to social responsibility, } \\
\text { related principles and considerations, and related actions and } \\
\text { expectations. }\end{array}$ \\
\hline $\begin{array}{l}\text { Guidance on } \\
\text { integrating social } \\
\text { responsibility } \\
\text { throughout } \\
\text { an organization }\end{array}$ & Clause 7 & $\begin{array}{l}\text { Provides guidance on putting social responsibility into practice in } \\
\text { an organization. This includes: understanding the social } \\
\text { responsibility of an organization, integrating social responsibility } \\
\text { throughout an organization, communication related to social } \\
\text { responsibility, improving the credibility of an organization } \\
\text { regarding social responsibility, reviewing progress and improving } \\
\text { performance and evaluating voluntary initiatives for social } \\
\text { responsibility. }\end{array}$ \\
\hline $\begin{array}{l}\text { Examples of voluntary } \\
\text { initiatives and tools for } \\
\text { social responsibility }\end{array}$ & Annex A & $\begin{array}{l}\text { Presents a non-exhaustive list of voluntary initiatives and tools } \\
\text { related to social responsibility that address aspects of one or more } \\
\text { core subjects or the integration of social responsibility throughout } \\
\text { an organization. }\end{array}$ \\
\hline Abbreviated terms & Annex B & Contains abbreviated terms used in ISO 26000. \\
\hline Bibliography & & cludes references to authoritative international instrumen \\
\hline
\end{tabular}

\subsection{Compliance Management System}

\section{Compliance Management System}

A CMS is how an organisation (1) learns about its compliance responsibilities, (2) ensures that employees understand these responsibilities, (3) ensures that requirements are incorporated into business processes (4) reviews operations to ensure responsibilities are carried out and requirements are met and (5) takes corrective action and updates materials as necessary. Some other notable new definitions include:

- Compliance - meeting all the organization's compliance obligations;

- Compliance obligations - commitments that an organisation has to or chooses to comply with;

- Compliance risk - effect of uncertainty on compliance objectives.

\subsection{ISO 19600}

ISO 19600:2014 provides guidance for establishing, developing, implementing, evaluating, maintaining and improving an effective and responsive compliance management system within an organization. The guidelines on compliance management systems are applicable to all types of organizations. The extent of the application of these guidelines depends on the size, structure, nature and complexity of the organization. ISO 19600 is based on the principles of good governance, proportionality, transparency and sustainability. It adapts PDCA process approach and compatible with ISO 9001, ISO 14001 ISO 22000, ISO 31000 and ISO 26000.

\subsection{Benefits}

By implementing a 19600 Compliance Management System the organisation will: (a) establish a system for evaluating and updating applicable legal requirements, (b) implement a framework for the identification of organizational risk associated with applicable legal requirements, (c) develop controls to ensure compliance with legal requirements, (d) ensure adherence with good governance practices.

\subsection{ISO 19600:2014 structure}

\begin{tabular}{|c|c|c|}
\hline Clause title & ${\text { Clause } n^{\circ}}^{\circ}$ & Description of clause contents \\
\hline Scope & Clause 1 & $\begin{array}{l}\text { Defines the scope of ISO } 19600 \text { and identifies certain } \\
\text { limitations and exclusions. }\end{array}$ \\
\hline Reference publications & Clause 2 & $\begin{array}{l}\text { Refers to other publications that provide information or } \\
\text { guidance. }\end{array}$ \\
\hline Terms and definitions & Clause 3 & $\begin{array}{l}\text { Identifies and provides the definition of key terms that } \\
\text { are of fundamental importance for understanding and } \\
\text { using ISO } 19600 \text {. }\end{array}$ \\
\hline $\begin{array}{l}\text { Context of the } \\
\text { organisation. }\end{array}$ & Clause 4 & $\begin{array}{l}\text { Deals with (a) analysis of the environment in which the } \\
\text { organisation operates (context, issues, stakeholders and } \\
\text { their requirements, needs and expectations), (b) scope of }\end{array}$ \\
\hline
\end{tabular}




\begin{tabular}{|c|c|c|}
\hline & & $\begin{array}{l}\text { the compliance management system, (c) identification } \\
\text { of compliance obligations and (d) assessment of the } \\
\text { compliance risks. }\end{array}$ \\
\hline Leadership & Clause 5 & $\begin{array}{l}\text { Discusses about (a) policy, commitment, leading by } \\
\text { example, (b) roles, responsibilities and authorities with } \\
\text { respect to compliance for the board, top and line } \\
\text { management, employees and an independent } \\
\text { compliance officer. }\end{array}$ \\
\hline Planning & Clause 6 & $\begin{array}{l}\text { (a) planning of measures to control compliance risks, } \\
\text { (b) establishing compliance objectives. }\end{array}$ \\
\hline Support & Clause 7 & $\begin{array}{l}\text { Ensures (a) awareness, competence and training in } \\
\text { compliance, (b) behaviour and culture and (c) } \\
\text { communication and documentation. }\end{array}$ \\
\hline Operations & Clause 8 & $\begin{array}{l}\text { Implementation of controls for compliance (technical, } \\
\text { procedural, directing the attitude and behaviour of } \\
\text { personnel). }\end{array}$ \\
\hline $\begin{array}{l}\text { Performance } \\
\text { evaluation }\end{array}$ & Clause 9 & $\begin{array}{l}\text { Ensures (a) monitoring of compliance, application of } \\
\text { indicators, (b) analysis of information and reporting of } \\
\text { results (internal and external) and (c) internal audit and } \\
\text { management review. }\end{array}$ \\
\hline Improvement & Clause 10 & $\begin{array}{l}\text { Discusses about (a) actions on non-compliance with } \\
\text { requirements and escalation to higher management } \\
\text { levels when necessary, (b) corrective action and (c) } \\
\text { improvement activities. }\end{array}$ \\
\hline
\end{tabular}

\subsection{Information security management system}

\section{Information Security Management Systems (ISMS)}

An Information Security Management System (ISMS) is a set of policies and procedures for systematically managing an organization's sensitive data. The goal of ISMS is to minimize risk and ensure business continuity by pro-actively limiting the impact of a security breach.

\subsection{ISO 27001}

ISO/IEC 27001:2013 adopts a process approach for establishing, implementing, maintaining and continually improving an information security management system within the context of the organization. It also includes requirements for the assessment and treatment of information security risks tailored to the needs of the organization. The series include: (a) ISO/IEC 27000, IT - Security techniques - ISMS - Overview and vocabulary, (b) ISO/IEC 27001, IT — Security techniques — ISMS - Requirements, (c) ISO/IEC 27002, IT Security techniques - ISMS - Code of practice for ISMS, (d) ISO/IEC 27003, IT - Security techniques ISM implementation guidance, (e) ISO/IEC 27004, IT - Security techniques - Information security management - Measurement, (f) ISO/IEC 27005, IT - Security techniques - Information security risk management. ISO 27001 follows the PDCA approach and can be combined with ISO 9001, ISO 14001 and ISO 22000 .

\subsection{Benefits}

The following are the benefits of implementing ISO 27001: (a) Credibility, trust and confidence of the customer, (b) Greater awareness of security, (c) Compliance with legislation, (d) Securing confidentiality, integrity and availability, (e) Prevention of confidentiality breaches, (f) Prevention of unauthorized alteration of critical information, (g) Prompt detection of data leakage and fast reaction, (h) Competitive advantage - deciding differentiator in contract negotiations, (i) Meeting international benchmarks of security.

\subsection{ISO 27001:2013 structure}

\begin{tabular}{|c|c|c|}
\hline Clause title & ${\text { Clause } \mathbf{n}^{\circ}}^{\circ}$ & Description of clause contents \\
\hline Introduction & & $\begin{array}{l}\text { The Plan-Do-Check-Act section has now been removed; } \\
\text { however Clause } 10 \text { still requires continual improvement. }\end{array}$ \\
\hline Scope & Clause 1 & $\begin{array}{l}\text { There is a stronger focus on assessment and treatment of risks } \\
\text { tailored to meet the needs of the organisation. Exclusions to } \\
\text { Clauses } 4 \text { to } 10 \text { are not permitted, however it does not refer to } \\
\text { exclusions of controls in Annex A. }\end{array}$ \\
\hline Normative references & Clause 2 & ISO/IEC 27001 is listed as the only normative reference. \\
\hline Terms and definitions & Clause 3 & $\begin{array}{l}\text { Terms and definitions reference is now made to ISO/IEC } \\
\text { 27000:2012. }\end{array}$ \\
\hline $\begin{array}{l}\text { Context of the } \\
\text { organisation }\end{array}$ & Clause 4 & $\begin{array}{l}\text { This clause requires the organisation to determine external and } \\
\text { internal issues. Risk management-Principles and guidelines } \\
\text { (4.1). Determining the needs and expectations of interested } \\
\text { parties (4.2). The scope of the ISMS needs to consider the } \\
\text { issues identified and the requirements of the interested parties } \\
\text { (4.3). The requirement to continually improve the ISMS is }\end{array}$ \\
\hline
\end{tabular}




\begin{tabular}{|c|c|c|}
\hline & & included in 4.4 . \\
\hline Leadership & Clause 5 & $\begin{array}{l}\text { This clause sets the requirements to be met by 'top } \\
\text { management'. The requirements and properties for an } \\
\text { information security policy are defined here. }\end{array}$ \\
\hline Planning & Clause 6 & $\begin{array}{l}\text { Clause 6.1.1 General - replaces previous preventive action } \\
\text { requirements, Clause } 6.1 .2 \text { Information security risk } \\
\text { assessment, Clause } 6.1 .3 \text { Information security risk treatment. } \\
\text { Controls are to be compared against those in Annex A to } \\
\text { verify that no necessary controls are omitted. Clause } 6.2 \\
\text { Information security objectives. }\end{array}$ \\
\hline Support & Clause 7 & $\begin{array}{l}\text { Requirements for determining and providing resources, and } \\
\text { determination of competence, awareness and communication } \\
\text { have little change from the previous version. Requirements for } \\
\text { control of documents and records have been revised and the } \\
\text { Standard now refers to "documented information" and control } \\
\text { of the documented information. }\end{array}$ \\
\hline Operation & Clause 8 & $\begin{array}{l}\text { This Clause equates to the old "implement and operate the } \\
\text { ISMS" and requires planning, implementing and controlling } \\
\text { processes to achieve objectives, performing risks assessments } \\
\text { and implementing risk treatment plans. It includes a specific } \\
\text { requirement that outsourced processes are determined and } \\
\text { controlled. }\end{array}$ \\
\hline Performance Evaluation & Clause 9 & $\begin{array}{l}\text { 9.1 Monitoring, measurement, analysis and evaluation, } 9.2 \\
\text { Internal audits and } 9.3 \text { Management review. }\end{array}$ \\
\hline Improvement & Clause 10 & $\begin{array}{l}\text { This Clause now requires organisations to react to } \\
\text { nonconformities and take action to control and correct them. } \\
\text { The requirement to continually improve the ISMS has been } \\
\text { expanded to include the suitability and adequacy of the ISMS } \\
\text { as well as the effectiveness. }\end{array}$ \\
\hline Controls & Annex A & $\begin{array}{l}\text { The number of controls has been reduced from } 133 \text { to } 114 \text {, } \\
\text { while the number of sections has increased from } 11 \text { to } 14 \text {. }\end{array}$ \\
\hline
\end{tabular}

\subsection{Energy Management Systems}

\section{Energy Management Systems (EnMS)}

An Energy Management System (EnMS) is a system of computer-aided tools used by operators of electric utility grids to monitor, control, and optimize the performance of the generation and/or transmission system. ISO 50001 supports organizations in all sectors to use energy more efficiently, through the development of an Energy Management System (EnMS).

\subsection{ISO 50001}

ISO 50001:2011 specifies requirements for establishing, implementing, maintaining and improving an energy management system, whose purpose is to enable an organization to follow a systematic approach in achieving continual improvement of energy performance, including energy efficiency, energy use and consumption. ISO 50001 follows PDCA process approach and can be combined with ISO 9001:2015 and ISO 14001:2015.

\subsection{Benefits}

ISO 50001 can provide organisations with a number of business benefits. These include: (a) helping to achieve energy use reduction and carbon emissions in a systematic way; (b) creating a clear picture of current energy use status, based on which new goals and targets can be set; (c) evaluating and prioritizing the implementation of new energy-efficient technologies and measures; (d) providing a framework to promote energy efficiency throughout supply chain; (e) providing guidance on how to benchmark, measure, document and report corporate energy use; (f) making better use of energy consuming assets, thus identifying potentials to reduce maintenance costs or expand capacity; (g) demonstrating to the stakeholders that corporate commitment to comply with their best practice to protect the environment; and (h) fulfilling the associated regulatory requirements and responding with confidence to green trade barriers in global market.

\subsection{ISO 50001:2011 structure}

\begin{tabular}{|l|l|l|}
\hline \multicolumn{1}{|c|}{ Clause title } & Clause $^{\circ}$ & \multicolumn{1}{c|}{ Description of clause contents } \\
\hline $\begin{array}{l}\text { General } \\
\text { Requirements }\end{array}$ & Clause 1 & $\begin{array}{l}\text { It requires the organisation to establish, document, implement and } \\
\text { improve its EnMS according to ISO 50001 standard. The } \\
\text { organisation should define and document the scope and } \\
\text { boundaries of its EnMS as well as how to achieve continual } \\
\text { improvement of its energy performance and EnMS. }\end{array}$ \\
\hline $\begin{array}{l}\text { Management } \\
\text { Responsibility }\end{array}$ & Clause 2 & $\begin{array}{l}\text { It requires the top management to demonstrate its commitment to } \\
\text { support and continually improve the effectiveness of the EnMS. It } \\
\text { requires the top management to appoint a management }\end{array}$ \\
\hline
\end{tabular}




\begin{tabular}{|c|c|c|}
\hline & & $\begin{array}{l}\text { representative(s) to promote awareness and oversee the } \\
\text { implementation of the EnMS. }\end{array}$ \\
\hline Energy Policy & Clause 3 & $\begin{array}{l}\text { It requires the organisation to define an energy policy to state its } \\
\text { commitment for achieving energy performance improvement. }\end{array}$ \\
\hline Energy Planning & Clause 4 & $\begin{array}{l}\text { It requires the organisation (a) to identify and have access to the } \\
\text { applicable legal and other requirements in relation to its energy } \\
\text { uses, consumption and efficiency to which it subscribes, (b) to } \\
\text { develop record and maintain an energy review as well as } \\
\text { document the methodology and criteria used to develop the } \\
\text { review. (Item } 4.4 .3 \text { ), (c) to establish an energy baseline(s) for the } \\
\text { measurement of the energy performance. (Item } 4.4 .4 \text { ), (d) to } \\
\text { identify appropriate energy performance indicators to monitor and } \\
\text { measure its energy performance. (Item 4.4.5), (e) to establish, } \\
\text { implement and maintain documented energy objectives, targets } \\
\text { and action plans specified outcome or achievement defined to } \\
\text { meet its energy policy related to improved energy performance. } \\
\text { (Item 4.4.6) }\end{array}$ \\
\hline $\begin{array}{l}\text { Implementation } \\
\text { and Operation }\end{array}$ & Clause 5 & $\begin{array}{l}\text { It requires the organisation (a) to ensure all staff and persons } \\
\text { related to significant energy uses are competent. (Item 4.5.2) - } \\
\text { EnMS Awareness, (b) to address internal communication in } \\
\text { relation to its energy performance and EnMS. The organisation } \\
\text { should also decide whether to communicate externally about its } \\
\text { energy policy, EnMS and energy performance. (Item 4.5.3), (c) to } \\
\text { establish, implement and maintain information to describe the } \\
\text { core elements of the EnMS and their interaction. (Item 4.5.4.1), } \\
\text { (d) to control all the EnMS documents. (Item 4.5.4.2), (e) to } \\
\text { identify and plan operations and maintenance activities which are } \\
\text { related to its significant energy uses in order to ensure that they } \\
\text { are carried out under specified conditions. (Item } 4.5 .5 \text { ) (f) to } \\
\text { consider energy performance improvement opportunities and } \\
\text { operational control in the design of facilities, equipment, systems } \\
\text { and processes that can have a significant impact on its energy } \\
\text { performance. (Item 4.5.6), (g) to inform suppliers that } \\
\text { procurement is partly evaluated on the basis of energy } \\
\text { performance when procuring services, products and equipment } \\
\text { that have an impact on significant energy use. (Item 4.5.7) }\end{array}$ \\
\hline $\begin{array}{l}\text { Performance } \\
\text { Audits (Checking) }\end{array}$ & Clause 6 & $\begin{array}{l}\text { It requires the organisation (a) to monitor measure and analyze } \\
\text { the key characteristics of its operations that determine energy } \\
\text { performance at planned intervals. Equipment used in monitoring } \\
\text { and measurement of key characteristics should be calibrated to } \\
\text { ensure data are accurate and repeatable. (Item 4.6.1), (b) to } \\
\text { evaluate compliance with legal requirements and other } \\
\text { requirements to which it subscribes related to its energy use and } \\
\text { consumption at planned intervals. (Item 4.6.2), (c) to conduct } \\
\text { internal audits regularly to ensure effective implementation of the } \\
\text { EnMS. (Item 4.6.3), (d) to address nonconformities by making } \\
\text { corrections, and by taking corrective action and preventive action. } \\
\text { (Item 4.6.4), (e) to establish and maintain records to demonstrate } \\
\text { conformity to the EnMS. (Item 4.6.5) }\end{array}$ \\
\hline $\begin{array}{l}\text { Management } \\
\text { Review }\end{array}$ & Clause 7 & $\begin{array}{l}\text { It requires the top management to review the EnMS regularly to } \\
\text { ensure its suitability, adequacy and effectiveness. (Item 4.7) }\end{array}$ \\
\hline
\end{tabular}

\subsection{Business Continuity Management Systems}

\section{Business Continuity Management Systems (BCMS)}

$\mathrm{BCM}$ is the development of strategies, plans and actions that provide protection or alternative modes of operation for those activities or business processes which, if they were to be interrupted, might otherwise bring about a seriously damaging or potentially significant loss to the enterprise. It is a part of the overall management system that establishes implements, operates, monitors, reviews, maintains and improve business continuity.

\section{BCM consists of three core elements:}

- Crisis management and communications is a process designed to enable an effective response to an event. Crisis management processes focus on stabilizing the situation and preparing the business for recovery operations through effective planning, leadership and communication protocols.

- Business resumption planning, or business recovery planning, involves the recovery of critical business functions and processes that relate to or support the delivery of core products or services to a customer.

- IT disaster recovery addresses the recovery of critical IT assets, including systems, applications, databases, storage and network assets. 


\subsection{ISO 22301}

ISO 22301:2012 is the international standard for business continuity management, and builds on the success of British Standard BS 25999 and other regional standards. It's designed to protect the business from potential disruption. This includes extreme weather, fire, flood, natural disaster, theft, IT outage, staff illness or terrorist attack. The ISO 22301 management system lets to identify threats relevant to the business and the critical business functions they could impact. It is supported by ISO 22313:2012, "Societal security -- Business continuity management systems - Guidance" which provides more pragmatic advice concerning business continuity management. ISO 22301 and 22313 adopts PDCA process model and is compatible with ISO 9001, ISO 14001 and ISO 27001.

\subsection{Benefits}

ISO 22301 compliant BCMS helps to ensure the ability to continue operating in an event of a business disruption and deliver real benefits (a) identify and manage current and future threats to the business, (b) take a proactive approach to minimizing the impact of incidents, (c) keep critical functions up and running during times of crises, (d) minimize downtime during incidents and improve recovery.

11.4 ISO 22301:2012 structure

\begin{tabular}{|c|c|c|}
\hline Clause title & Clause $^{\circ}$ & Description of clause contents \\
\hline Scope & Clause 1 & $\begin{array}{l}\text { Defines the scope of ISO } 22301 \text { and identifies certain limitations and } \\
\text { exclusions. }\end{array}$ \\
\hline Normative references & Clause 2 & Refers to other publications that provide information or guidance. \\
\hline Terms and definitions & Clause 3 & $\begin{array}{l}\text { Identifies and provides the definition of key terms that are of } \\
\text { fundamental importance for BCM and for using ISO } 22301 \text {. }\end{array}$ \\
\hline $\begin{array}{l}\text { Context of the } \\
\text { organisation }\end{array}$ & Clause 4 & $\begin{array}{l}\text { It introduces requirements necessary to establish the context of BCMS } \\
\text { as it applies to the organisation, as well as needs requirements and } \\
\text { scope. }\end{array}$ \\
\hline Leadership & Clause 5 & $\begin{array}{l}\text { It summarizes the requirements specific to top management role in } \\
\text { BCMS and how leadership articulates its expectations to the } \\
\text { organisation through a policy statement }\end{array}$ \\
\hline Planning & Clause 6 & $\begin{array}{l}\text { It describes requirements as it relates to establishing strategic } \\
\text { objectives and guiding principles for the BCMS as a whole. The } \\
\text { content of clause } 6 \text { differs from establishing risk treatment } \\
\text { opportunities stemming from risk assessment, as well as business } \\
\text { impact analysis (BIA) derived recovery objectives. }\end{array}$ \\
\hline Support & Clause 7 & $\begin{array}{l}\text { It supports BCMS operations as it relates to establishing, competence } \\
\text { and communication on a recurring/as-needed basis with interested } \\
\text { parties, while documenting, controlling, maintaining and retaining } \\
\text { required documentation. }\end{array}$ \\
\hline Operation & Clause 8 & $\begin{array}{l}\text { It defines business continuity requirements, determines how to address } \\
\text { them and develops the procedures to manage a disruptive event. }\end{array}$ \\
\hline Performance Evaluation & Clause 9 & $\begin{array}{l}\text { It summarizes requirements to measure business continuity } \\
\text { management performance, BCMS compliance with this international } \\
\text { standard and management expectations, and seeks feedback from } \\
\text { management regarding expectations. }\end{array}$ \\
\hline Improvement & Clause 10 & $\begin{array}{l}\text { It identifies and acts on BCMS non-conformance through corrective } \\
\text { action. }\end{array}$ \\
\hline
\end{tabular}

\section{Event Sustainability Management Systems (ESMS)}

\subsection{Event Sustainability Management Systems}

Event Sustainability Management Systems (ESMS) provides specific requirements for the organisation of events with lower impact on environment and community, and improved relationship with a broad range of stakeholders: local authorities, suppliers, residents, workers, and of course participants and attendees of the event.

\subsection{ISO 20121}

ISO 20121:2012 certification is applicable to any organisation that aims to: (a) establish, implement, maintain and improve an event sustainability management system; (b) ensure that it is in conformity with its stated sustainable development policy; (c) demonstrate voluntary conformity with this International Standard by the organizers, and any second party having an interest in the organisation. ISO 20121 follows PDCA approach and is compatible with ISO 9001:2015 and ISO 14001:2015.

\subsection{Benefits}

The key benefits of ISO 20121 ESMS include: (a) identify cost savings, (b) develop the event image and credibility, (c) quantify, monitor and control the impact on the environment, through continuous improvement, (d) ensure awareness and compliance to regulations for the organisation of events, (e) improve environmental performance of the event supply chain, (f) grow the access to sponsors and larger audience for the event. 
12.4 ISO 20121:2012 structure

\begin{tabular}{|c|c|c|}
\hline Clause title & ${\text { Clause } n^{\circ}}^{\circ}$ & Description of clause contents \\
\hline Scope & Clause 1 & $\begin{array}{l}\text { Defines the scope of ISO } 20121 \text { and identifies certain limitations } \\
\text { and exclusions. }\end{array}$ \\
\hline Normative references & Clause 2 & $\begin{array}{l}\text { Refers to other publications that provide information or } \\
\text { guidance. }\end{array}$ \\
\hline Terms and definitions & Clause 3 & $\begin{array}{l}\text { Identifies and provides the definition of key terms that are of } \\
\text { fundamental importance for event sustainability management and } \\
\text { for using ISO } 20121 \text {. }\end{array}$ \\
\hline $\begin{array}{l}\text { Context of the } \\
\text { organisation }\end{array}$ & Clause 4 & $\begin{array}{l}\text { It identifies and engage interested parties, determines the scope } \\
\text { of the management system and defines governing principles of } \\
\text { sustainable development. }\end{array}$ \\
\hline Leadership & Clause 5 & $\begin{array}{l}\text { It summarizes the requirements specific to top management role } \\
\text { in event sustainability management system and how leadership } \\
\text { articulates its expectations to the organisation through a policy } \\
\text { statement. }\end{array}$ \\
\hline Planning & Clause 6 & $\begin{array}{l}\text { It describes requirements as it relates to establishing strategic } \\
\text { objectives and guiding principles for the event sustainability } \\
\text { management system as a whole. It discusses about the actions to } \\
\text { address risks and opportunities and event sustainability } \\
\text { objectives and how to achieve them. It Identifies and evaluate } \\
\text { issues, sets objectives and plans to achieve them. }\end{array}$ \\
\hline Support & Clause 7 & $\begin{array}{l}\text { It provides resources and ensure sufficient competencies and } \\
\text { awareness, maintains internal and external communications, } \\
\text { creates and maintain documentation and procedures required for } \\
\text { system effectiveness. }\end{array}$ \\
\hline Operation & Clause 8 & $\begin{array}{l}\text { It defines business continuity requirements, determines how to } \\
\text { address them and develops the procedures to manage a disruptive } \\
\text { event. }\end{array}$ \\
\hline Performance Evaluation & Clause 9 & $\begin{array}{l}\text { It summarizes requirements to measure ESMS compliance with } \\
\text { this international standard and management expectations, and } \\
\text { seeks feedback from management regarding expectations. }\end{array}$ \\
\hline Improvement & Clause 10 & $\begin{array}{l}\text { It identifies and acts on ESMS non-conformance through } \\
\text { corrective action. }\end{array}$ \\
\hline Annex A & & $\begin{array}{l}\text { Guidance on planning and implementing this International } \\
\text { Standard. }\end{array}$ \\
\hline Annex B & & Supply chain management. \\
\hline Annex C & & Evaluation. \\
\hline
\end{tabular}

\section{Supply Chain Security Management Systems (SCSMS)}

\subsection{Supply Chain Security Management Systems}

A supply chain security management system combines traditional supply chain management practices with security measures allowing protecting the business against threats such as piracy, terrorism and theft. Important aspects of security management include validating supplier credentials, screening cargo and securing cargo transit. Some of the types of common security are Container / Trailer Security, Conveyance Security, Personnel Security, Procedure Security, Physical Security and Information Security.

\subsection{ISO 28000}

ISO 28000:2007 is applicable to all sizes of organizations, from small to multinational, in manufacturing, service, storage or transportation at any stage of the production or supply chain that wishes to: (a) establish, implement, maintain and improve a security management system; (b) assure conformance with stated security management policy; (c) demonstrate such conformance to others; (d) seek certification/ registration of its security management system by an Accredited third party Certification Body; (e) make a selfdetermination and self-declaration of conformance with ISO 28000:2007.

ISO 28000 series consists of: (a) ISO 28000:2007 - Specification for security management systems for the supply chain, (b) ISO 28001:2007 - Best practices for implementing supply chain security, assessments and plans - Requirements and guidance, (c) ISO 28003:2007 - Requirements for bodies providing audit and certification of supply chain security management systems, (d) ISO 28004:2007 - Guidelines for the implementation of ISO 28000 - Proper implementation and operation of a security management system will provide improved security and deliver tangible benefits. ISO 28000 adopts PDCA process approach and can be aligned with ISO 9001, ISO 14001 and OHSAS 18001 to facilitate the integration with other management systems. 


\subsection{Benefits}

The benefits of SCSMS are (a) improve stakeholder confidence by demonstrating more robust an secure supply chain management, (b) enhances customer satisfaction by demonstrating ability to meet their specific requirements, (c) make the organization a supplier of choice by demonstrating the organization's capability to manage security issues within supply chain, (d) demonstrate systematic Supply Chain Security management, (e) develops business cooperation along supply chain, (f) shorten customs clearance time and reduce secondary inspection and (g) facilitate compliance with other official trade and supply chain processes.

\subsection{ISO 28000:2007 structure}

\begin{tabular}{|c|c|c|}
\hline Clause title & Clause $^{\circ}$ & Description of clause contents \\
\hline Scope & Clause 1 & $\begin{array}{l}\text { Defines the scope of ISO } 28000 \text { and identifies certain limitations and } \\
\text { exclusions. }\end{array}$ \\
\hline Normative references & Clause 2 & Refers to other publications that provide information or guidance. \\
\hline Terms and definitions & Clause 3 & $\begin{array}{l}\text { Identifies and provides the definition of key terms that are of } \\
\text { fundamental importance for Supply Chain Security Management } \\
\text { Systems (SCSMS) and for using ISO } 28000 \text {. }\end{array}$ \\
\hline $\begin{array}{l}\text { Security management } \\
\text { system elements }\end{array}$ & Clause 4 & $\begin{array}{l}\text { It identifies and engages interested parties, determines the scope of the } \\
\text { management system and defines governing principles of sustainable } \\
\text { development. }\end{array}$ \\
\hline General requirements & Clause 4.1 & $\begin{array}{l}\text { It discusses about an effective security management system for } \\
\text { identifying security threats, assessing risks, controlling and mitigating } \\
\text { their consequences. }\end{array}$ \\
\hline $\begin{array}{l}\text { Security management } \\
\text { policy }\end{array}$ & Clause 4.2 & $\begin{array}{l}\text { The SMS must also have a process for assessing the security } \\
\text { environment in which it operates and for determining if adequate } \\
\text { security measures are in place. This examination of the operational } \\
\text { environment includes regulatory requirements as well as the physical, } \\
\text { natural and human hazards and specific industry requirements. }\end{array}$ \\
\hline $\begin{array}{l}\text { Security risk assessment } \\
\text { and planning }\end{array}$ & Clause 4.3 & $\begin{array}{l}\text { ISO } 28000 \text { articulates a strategy for assessment of risk and determining } \\
\text { counter measures as a core component of providing physical security for } \\
\text { the organization. }\end{array}$ \\
\hline $\begin{array}{l}\text { Implementation and } \\
\text { operation }\end{array}$ & Clause 4.4 & $\begin{array}{l}\text { ISO } 28000 \text { identifies requirements for implementing and operating a } \\
\text { SMS, including organizational (security) structure, authorized personnel } \\
\text { responsible for security management, assessing and maintaining }\end{array}$ \\
\hline $\begin{array}{l}\text { Checking and corrective } \\
\text { action }\end{array}$ & Clause 4.5 & $\begin{array}{l}\text { Corrective and preventive actions, based on monitoring and evaluation } \\
\text { of the SMS, must be implemented to address any security-related } \\
\text { failures and address in a timely fashion any non-conformities that are }\end{array}$ \\
\hline $\begin{array}{l}\text { Management review } \\
\text { and continual } \\
\text { improvement }\end{array}$ & Clause 4.6 & $\begin{array}{l}\text { Records generated as part of the operation of the SMS, results of audits } \\
\text { and risk assessments, legal and regulatory requirements are submitted } \\
\text { for review along with input from interested parties and recommendations } \\
\text { for improvement. Output from management review must include } \\
\text { guidance for the organization to improve the SMS through changes to }\end{array}$ \\
\hline Annex A & & Correspondence between ISO 28000, ISO 14001 and ISO 9001 \\
\hline Bibliography & & \\
\hline
\end{tabular}

\subsection{IT Service Management Systems}

\section{IT Service Management System (ITSM)}

IT Service Management is a strategic approach to designing, delivering, managing and improving the way information technology (IT) is used within an organization. The goal of IT Service Management is to ensure that the right processes, people and technology are in place to meet organisation business goals.

\subsection{ISO 20000}

ISO 20000:2011 helps service providers to understand how to boost the quality of their services to all customers - including staff members. This standard shares practical solutions to processes that can be implemented by any organization, regardless of its size or structure. The requirements set out in ISO 20000 apply to both large and small service providers and help them to deliver the best possible services to meet their customers' needs. IEC 20000 requires an integrated process approach when the service provider plans, establishes, implements, operates, monitors, reviews, maintains and improves a service management system (SMS). ISO/IEC 20000-2:2012 (Code of Practice) provides guidance on the application of Service Management Systems (SMS) based on the requirements in ISO/IEC 20000-1:2011. ISO/IEC TR 20000-3:2009 provides guidance on scope definition, applicability and demonstration of conformance for service providers aiming to meet the requirements of ISO/IEC 20000-1. ISO/IEC TR 20000-4:2010 (Process Reference Model) is intended to facilitate the development of a process assessment model according to ISO/IEC 15504 process assessment principles. ISO/IEC 15504-1 describes the concepts and terminology used for process assessment. ISO/IEC TR 20000-5:2010 is an exemplar implementation plan providing guidance to service providers on how to implement a service management system to fulfil the requirements of ISO/IEC 20000-1. 
ISO 20000 promotes the adoption of an integrated process approach to delivering managed IT services. The standard is aligned and fully compatible with the ITIL (Information Technology Infrastructure Library) framework. ISO 20000 also aligns with ISO 9001:2015 and ISO 27001:2013.

\subsection{Benefits}

Implementation of ISO 20000 brings with it many benefits and advantages: (a) alignment of information technology services and business strategy, (b) creation of a formal framework for current service improvement projects, (c) provides a benchmark type comparison with best practices, (d) creates competitive advantage via the promotion of consistent and cost-effective services, (e) supports 'interchanging' of service providers and staff by virtue of the creation of inter-enterprise operational processes, (f) reduction of risk and thus cost in terms of external service receipt, (g) through the creation of a standard consistent approach, aids major organizational changes, (h) enhanced reputation and perception, (i) fundamental shift to pro-active rather than re-active processes, (j) creation of a stable framework for both resource training and service management automation.

\subsection{ISO 20000:2011 structure}

\begin{tabular}{|c|c|c|}
\hline Clause title & ${\text { Clause } n^{\circ}}^{\circ}$ & Description of clause contents \\
\hline Scope & Clause 1 & Defines the scope of ISO 20000 and identifies certain \\
\hline Normative references & Clause 2 & Refers to other publications that provide information or \\
\hline Terms and definitions & Clause 3 & $\begin{array}{l}\text { Identifies and provides the definition of key terms that are of } \\
\text { fundamental importance for IT-SMS and for using ISO } 20000 \text {. }\end{array}$ \\
\hline $\begin{array}{l}\text { Service management } \\
\text { system general } \\
\text { requirements }\end{array}$ & Clause 4 & $\begin{array}{l}\text { Discusses about management responsibilities, governance of } \\
\text { process operated by other bodies, documentation management, } \\
\text { services management system planning and implementation. }\end{array}$ \\
\hline $\begin{array}{l}\text { Design and transition of } \\
\text { new or changed services }\end{array}$ & Clause 5 & $\begin{array}{l}\text { Clause } 5.1 \text { re-emphasizes change management as the prime } \\
\text { controlling process. Clauses } 5.2 \text { and } 5.3 \text { list quite } \\
\text { comprehensive requirements for planning, design and } \\
\text { development of new or changed services. } 5.4 \text { Transition of new } \\
\text { or changed services redefines requirements for pre-deployment } \\
\text { service testing against service provider and stakeholder pre- } \\
\text { agreed acceptance criteria, use of the revised release and } \\
\text { deployment control process to migrate the service into the live } \\
\text { environment and a post-deployment review against expected } \\
\text { outcomes. }\end{array}$ \\
\hline $\begin{array}{l}\text { Service delivery } \\
\text { processes }\end{array}$ & Clause 6 & $\begin{array}{l}\text { Deals with service management, service reporting, service } \\
\text { continuity and available management, budgeting and accounting } \\
\text { for services, capacity management, information security } \\
\text { management, Information security changes and incidents. }\end{array}$ \\
\hline Relationship processes & Clause 7 & $\begin{array}{l}\text { Discusses about business relationship management and supplier } \\
\text { management. }\end{array}$ \\
\hline Resolution processes & Clause 8 & $\begin{array}{l}\text { Discusses about Incident and service request management and } \\
\text { problem management. }\end{array}$ \\
\hline Control processes & Clause 9 & $\begin{array}{l}\text { Discusses about configuration, change, release and deployment } \\
\text { management. }\end{array}$ \\
\hline Appendix A & & $\begin{array}{l}\text { Service management system general requirements compared } \\
\text { with ISO } 9001 \text { \& ISO } 27001 \text {. }\end{array}$ \\
\hline
\end{tabular}

\section{Food Safety Management System (FSMS)}

\subsection{Food Safety Management System}

A Food Safety Management System (FSMS) is a network of interrelated elements that combine to ensure that food does not cause adverse human health effects. This includes programs, plans, policies, procedures, practices, processes, goals, objectives, methods, controls, roles, responsibilities, relationships, documents, records, and resources. The standard ensures food safety from farm to fork based on these generally recognized key elements:

- Interactive communication: A structured informative flow in every direction, internally and externally. It guarantees effective control of hazards.

- System management: The control of the interaction between the system's elements guarantees efficiency and the effectiveness of the system.

- Prerequisite programmes: Good Manufacturing Practices, Hygiene Practices, Agricultural Practices, including e.g. equipment and buildings maintenance programmes and procedures, and pest control programmes, are the pillars on which a HACCP system is based.

- HACCP principles: Hazard Analysis and Critical Control Points methodology is to plan safe production processes which are appropriate for every individual company, without unnecessary bureaucracy. 


\subsection{ISO 22000}

ISO 22000 is applicable to all organisations directly or indirectly involved in the food value chain. This includes producers of packaging or detergents, suppliers of cleaning services, pest control, or industrial laundry services. It allows to assess and demonstrate conformity of the product in relation to food safety and to demonstrate control of food safety hazards.

The ISO 22000 family contains a number of standards each focusing on different aspects of food safety management. (a) ISO 22000:2005 contains the overall guidelines for food safety management, (b) ISO 22004:2014 provides generic advice on the application of ISO 22000, (c) ISO 22005:2007 focuses on traceability in the feed and food chain, (d) ISO/TS 22002-1:2009 contains specific prerequisites for food manufacturing, (e) ISO/TS 22002-2:2013 contains specific prerequisites for catering, (f) ISO/TS 22002-3:2011 contains specific prerequisites for farming, (g) ISO/TS 22002-4:2013 contains specific prerequisites for food packaging manufacturing, (h) ISO/TS 22003:2013 provides guidelines for audit and certification bodies.

ISO 22000, Food safety management systems -- Requirements for any organization in the food chain is under revision, with the draft version available for purchase from mid 2016. The final updated version is expected early 2017.

\subsection{ISO 22000 approach}

ISO 22000 follows PDCA approach, incorporates the hygiene measures of Prerequisite programs, and adds HACCP principles and criteria. The process described in ISO 22000 includes the following steps:

- Identify, evaluate, and control the food safety hazards that may be expected to occur in order to avoid harming the consumer directly or indirectly

- Communicate appropriate information through the food chain regarding safety issues related to the product

- Communicate information concerning development, implementation, and updating of the food safety management system throughout the organisation

- Evaluate periodically and update, when necessary, the food safety management system to cover the company's actual activities and the most recent information on food safety hazards

The processes of producing the food product or delivering the service are called product or service "Realization Processes". These processes must be carefully planned. Prerequisite programs (PRPs) must be in place to address the basic conditions and activities that are necessary to maintain a hygienic environment for the realization processes. This may include: good agricultural practices, good veterinarian practices, good manufacturing processes, good hygienic practices, good production practice, good distribution practices or good trading practices.

The food safety team will then create and implement a Hazard Analysis and Critical Control Point plan (HACCP Plan) for each product or process. The HACCP plan starts with some preliminary steps such as identifying product characteristics, describing intended use, preparing flow diagrams and describing process steps. The team uses this information to identify hazards that can be expected to occur, determine acceptable levels of the hazard and select control measures. The team identifies the control point where the hazard can be controlled, and the specific step that needs to be taken to successfully control the hazard. The plan for controlling the hazard must be documented and include the hazard to be controlled, the control measure, critical limits, how the control point will be monitored, corrections and corrective actions to be taken if limits are exceeded, responsibilities and authorities and required records.

The food safety team will also establish a plan for verification activities to ensure that the PRPs are implemented, inputs to hazard analysis are updated, the operational PRPs and HACCP plan are implemented and effective and the hazard levels are within limits. Verification activities make sure the HACCP system is in compliance, helping to ensure the effectiveness of the ISO 22000 system. The ISO 22000 standard is compatible and can be applied on its own, or in combination with other management system standards such as ISO 9001:2015.

\subsection{Benefits}

The benefits of implementing ISO 22000 are: (a) introduce internationally recognized processes to the business, (b) give suppliers and stakeholders' confidence in hazard controls, (c) put these hazard controls in place across the supply chain, (d) introduce transparency around accountability and responsibilities, (e) continually improve and update the systems so it stays effective, (f) greater impact on customers, (g) increased transparency, (h) streamlined production, (i) minimization of significant food risks, (j) effective control of internal processes and minimizing risk of failure, (h) increased staff motivation by focusing on a job well done, (i) signal sent about a proactive approach to food safety, (j) focus kept on the essential challenges. 


\subsection{ISO 22000:2005 Structure}

\begin{tabular}{|c|c|c|}
\hline Clause title & Clause $n^{\circ}$ & Description of clause contents \\
\hline Scope & Clause 1 & $\begin{array}{l}\text { Defines the scope of ISO } 22000 \text { and identifies certain limitations and } \\
\text { exclusions. }\end{array}$ \\
\hline Normative references & Clause 2 & Refers to other publications that provide information or guidance. \\
\hline Terms and definitions & Clause 3 & $\begin{array}{l}\text { Identifies and provides the definition of key terms that are of } \\
\text { fundamental importance for food safety management system and for } \\
\text { using ISO } 22000 \text {. }\end{array}$ \\
\hline $\begin{array}{l}\text { Food Safety Management } \\
\text { System }\end{array}$ & Clause 4 & $\begin{array}{l}\text { It discusses about the general requirements, documentation requirements } \\
\text { for ISO } 22000 \text { standards. }\end{array}$ \\
\hline $\begin{array}{l}\text { Management } \\
\text { responsibility }\end{array}$ & Clause 5 & $\begin{array}{l}\text { It discusses about the management responsibility, food safety policy, } \\
\text { responsibility and authority, food safety team leader, communication } \\
\text { and management review. }\end{array}$ \\
\hline Resource management & Clause 6 & $\begin{array}{l}\text { It details out the human resources, competence, awareness and training, } \\
\text { infrastructure and work environment. }\end{array}$ \\
\hline $\begin{array}{l}\text { Planning and realization } \\
\text { of safe products }\end{array}$ & Clause 7 & $\begin{array}{l}\text { It describes the Pre-Requiste Programme (PRPs), preliminary steps to } \\
\text { enable hazard analysis, product characteristics, flow digrams, process } \\
\text { steps and control measures, Hazard analysis, HACCP plan, control of } \\
\text { non-conformity. }\end{array}$ \\
\hline $\begin{array}{l}\text { Validation, verification \& } \\
\text { improvement of FSMS }\end{array}$ & Clause 8 & $\begin{array}{l}\text { It discusses about validation, verification and improvement of food } \\
\text { safety management system. }\end{array}$ \\
\hline Annex A & & Cross references between ISO 22000:2005 and ISO 9001:2015. \\
\hline Annex B & & Cross references between HACCP and ISO 22000:2005. \\
\hline Annex C & & $\begin{array}{l}\text { Codex references providing examples of control measures, including } \\
\text { prerequisite programmed and guidance for their selection and use. }\end{array}$ \\
\hline
\end{tabular}

\section{Risk Management}

\subsection{Risk Management}

Risk management is the identification, assessment, and prioritization of risks followed by coordinated and economical application of resources to minimize, monitor, and control the probability of unfortunate events.

\subsection{ISO 31000}

ISO 31000 standard sets out principles, a framework and a process for the management of risk that is applicable to any type of organization in the public or private sector. The generic approach described in this standard provides the principles and guidelines for managing any form of risk in a systematic, transparent and credible manner and within any scope and context.

\subsection{Benefits}

The following are the benefits of implementing ISO 31000: (a) creates and protects value, (b) is an integral part of all organizational processes, (c) is part of decision making, (d) explicitly addresses uncertainty, (e) systematic, structured and timely, (f) takes human and cultural factors into account, (g) transparent and inclusive, (h) dynamic, iterative and responsive to change and (i) facilitates continual improvement of the organization.

\subsection{ISO 31000:2009 structure}

\begin{tabular}{|c|c|c|}
\hline Clause title & ${\text { Clause } n^{\circ}}^{\prime}$ & Description of clause contents \\
\hline Scope & Clause 1 & $\begin{array}{l}\text { Defines the scope of ISO } 31000 \text { and identifies certain limitations } \\
\text { and exclusions. }\end{array}$ \\
\hline Terms and definitions & Clause 2 & $\begin{array}{l}\text { Identifies and provides the definition of key terms that are of } \\
\text { fundamental importance for understanding risk management and } \\
\text { for using ISO } 31000 \text {. }\end{array}$ \\
\hline $\begin{array}{l}\text { Risk management } \\
\text { principles }\end{array}$ & Clause 3 & $\begin{array}{l}\text { It discusses about the risk management principles than an } \\
\text { organization should comply with at all levels to make the risk } \\
\text { management effective. }\end{array}$ \\
\hline $\begin{array}{l}\text { Risk management } \\
\text { framework }\end{array}$ & Clause 4 & $\begin{array}{l}\text { It details about the risk management framework and the } \\
\text { relationship between the components of the framework for } \\
\text { managing risk. The components are mandate and commitment, } \\
\text { design of framework for managing risk, implementing risk } \\
\text { management, monitoring and review of the framework, continual } \\
\text { improvement of the framework. }\end{array}$ \\
\hline $\begin{array}{l}\text { Risk management } \\
\text { process }\end{array}$ & Clause 5 & $\begin{array}{l}\text { It includes communication and consultation, establishing the } \\
\text { context, risk assessment (identification, analysis and evaluation), } \\
\text { risk treatment, monitoring and review and recording the risk } \\
\text { management process. }\end{array}$ \\
\hline $\begin{array}{l}\text { Attributes of enhanced } \\
\text { risk management }\end{array}$ & Annex A & $\begin{array}{l}\text { It covers continual improvement, full accountability for risks, } \\
\text { application of risk management in all decision making, continual } \\
\text { communications and full risk integration in the organization's } \\
\text { governance structure }\end{array}$ \\
\hline ibliography & & \\
\hline
\end{tabular}




\section{Key Performance Indicators (KPIs) for Manufacturing Operations}

\subsection{Key Performance indicators (KPIs) for Manufacturing Operations}

Key Performance Indicators are factors that are tracked by organizations to analyze their manufacturing processes. These criteria are used to measure success relative to a set of predetermined goals or objectives. KPIs are very important for understanding and improving manufacturing performance, both from the lean manufacturing perspective of eliminating waste and from the corporate perspective of achieving strategic goals. MOM, sometimes referred to as Manufacturing Execution Systems (MES), models four major categories of operations management: (a) production operations management; (b) maintenance operations management; (c) quality operations management; and (d) inventory operations management.

Visual management is a system in which KPIs are displayed on a factory floor to provide clear, visible objectives to the front line employees. Criteria relating to production output, quality, and efficiency clearly displayed in order to encourage higher performance by employees. It provides actionable information so that performance can be easily monitored and improvements can be made quickly to improve efficiency.

\subsection{ISO 22400}

ISO 22400:2014 defines key performance indicators (KPIs) used in manufacturing operations management. ISO 22400 specifies an industry-neutral framework for defining, composing, exchanging, and using key performance indicators (KPIs) for manufacturing operations management (MOM), as defined in IEC 62264-1 for batch, continuous and discrete industries.

ISO 22400-1:2014: (a) provides an overview of what a KPI is, (b) presents concepts of relevance for working with KPIs including criteria for constructing KPIs, (c) specifies terminology related to KPIs, and (d) describes how a KPI can be used. ISO 22400-2:2014 specifies a selected number of KPIs in current practice. The KPIs are presented by means of their formula and corresponding elements, their time behaviour, their unit/dimension and other characteristics. The ISO 22400 KPIs for Manufacturing Operations Management consist of four parts; two parts are under development, and two parts under consideration: (a) ISO 22400-1: Part 1: Overview, concepts and terminology, (b) ISO 22400-2: Part 2: Definitions and Descriptions, (c) ISO 224003: Part 3: Exchange and use, (d) ISO 22400-4: Part 4: Relationships and dependencies.

\subsection{Benefits}

Key performance indicators help to ensure that the processes are efficient and that the goals set by the organization are being monitored and reached. The KPIs defined in the standard are intended to be examples of the most frequently used KPIs at the Manufacturing Operations level in industry today, i.e. a palette of KPIs from which companies can select the one that best corresponds to their business objective. It is recognized that some of the KPIs are better suited for discrete industry and others are better suited for continuous/process industry. ISO 22400-2 defines thirty four (34) KPIs as shown below:

\begin{tabular}{|c|c|c|}
\hline - Worker Efficiency & - Production process ratio & - Finished goods ratio \\
\hline - Allocation Ratio & - Actual to planned scrap ratio & - Integrated goods ratio \\
\hline - Throughput rate & - First pass yield & - Production loss ratio \\
\hline - Allocation efficiency & - Scrap ratio & $\begin{array}{l}\text { - Storage and transportation loss } \\
\text { ratio }\end{array}$ \\
\hline - Utilization efficiency & - Rework ratio & - Other loss ratio \\
\hline $\begin{array}{ll}\text { - Overall equipment } \\
\text { effectiveness index }\end{array}$ & - $\quad$ Fall off ratio & - Equipment load ratio \\
\hline $\begin{array}{l}\text { - Net equipment effectiveness } \\
\text { index }\end{array}$ & - Machine capability index & $\begin{array}{l}\text { - Mean operating time between } \\
\text { failures }\end{array}$ \\
\hline - Availability & $\begin{array}{ll}\text { - Critical machine capability } \\
\text { index }\end{array}$ & - Mean time to failure \\
\hline - Effectiveness & - Process capability index & - Mean time to restoration \\
\hline - Quality Ratio & $\begin{array}{lll} & \text { Critical process capability } \\
\text { index }\end{array}$ & - Corrective maintenance ratio \\
\hline - Setup Rate & - Comprehensive & \\
\hline - Technical efficiency & - Inventory turns & \\
\hline
\end{tabular}

Each KPI is defined though a formula, a time model and an effect model.

- The formula presents the equation that should use for deriving the numerical value of the KPI. The equation is an aggregation function of, physical measurements, data and/or other KPIs.

- The time model is used to visualize information about physical measurements used in the aggregation functions. The time models visualize start/stop time for specific measurements, as well as its relationship to other physical measurements etc.

- The effect model can be seen as a root-cause diagram. Each KPI has its own effect model. The effect model is a picture that highlights the relationship between the KPI and its parameters. 


\begin{tabular}{|c|c|c|}
\hline Clause title & ${\text { Clause } n^{\circ}}^{\circ}$ & Description of clause contents \\
\hline Scope & Clause 1 & $\begin{array}{l}\text { Defines the scope of ISO } 22400 \text { and identifies certain limitations and } \\
\text { exclusions. }\end{array}$ \\
\hline Normative references & Clause 2 & Refers to other publications that provide information or guidance. \\
\hline Terms and definitions & Clause 3 & $\begin{array}{l}\text { Identifies and provides the definition of key terms that are of } \\
\text { fundamental importance for understanding social responsibility and for } \\
\text { using ISO } 22400 \text {. }\end{array}$ \\
\hline $\begin{array}{l}\text { Symbols and } \\
\text { abbreviated terms }\end{array}$ & Clause 4 & $\begin{array}{ll}\text { - } & \text { KPI Key Performance Indicator } \\
\text { - } & \text { MOM Manufacturing Operations Management } \\
\text { - } & \text { UML Unified Modeling Language } \\
\text { - } & \text { URL Uniform Resource Locator } \\
\text { - } & \text { XML eXtensible Mark-up Language }\end{array}$ \\
\hline $\begin{array}{l}\text { Concepts and } \\
\text { terminology }\end{array}$ & Clause 5 & $\begin{array}{l}\text { It discusses about the concept of key performance indicator, Categories } \\
\text { of operations, Operations performance measurement, Context for } \\
\text { performance indicators, Characteristics of KPIs, Use and exchange of } \\
\text { KPIs. }\end{array}$ \\
\hline Conformance & Clause 6 & $\begin{array}{l}\text { Objects of conformity assessment using ISO } 22400 \text { may be products } \\
\text { (including services), processes, or systems. }\end{array}$ \\
\hline $\begin{array}{l}\text { Manufacturing } \\
\text { operations categories }\end{array}$ & Annex A & $\begin{array}{l}\text { It describes about Production operations domain, Inventory handling } \\
\text { operations domain, Quality assurance testing operations domain, } \\
\text { Maintenance operations domain and Other operations domain }\end{array}$ \\
\hline Bibliography & & \\
\hline
\end{tabular}

\section{Discussion}

An IMS needs to be structured to enable the organisation to effectively and efficiently manage its processes and will depend on the organization's size, the number and complexity of processes, products and services, and related risks, degree of regulation and whether it is national or multinational etc.

A well-defined integrated system can have multiple benefits: (a) effective utilization of time due to combined efforts; (b) relatively simple, less documentation, (c) Less audit time, and resulting more time available for Management \& audits and (d) get the overall picture of system weaknesses in balanced manner. Ideally, the organisation should have an Integrated Management System that runs the organization and addresses all of the objectives at once, whatever they may be. It is a challenge to satisfy the requirements of several management systems while running a business but achieving this can be beneficial to the organization's efficiency and effectiveness, as well as reducing the cost and disruption of external audits.

\section{Recommendation}

Integrate multiple management systems to optimize the organization's efficiency. Certification registrar's offers integrated audit programs to assess compliance with requirements for a combination of management systems established in the organization. An integrated management system will improve the business' efficiency as it reduces costs and disruption by external audits. Once the organization is certified to an individual standard or certified to multiple standards, the next logical step to ensure minimum efforts are spent on system maintenance and get maximum benefits from certification. Standards against which the existing management systems may be simultaneously certified through an integrated audit include: (a) ISO 9001 Quality Management Systems, (b) ISO 14001 Environmental Management Systems, (c) OHSAS 18001 Occupational Health \& Safety Management Systems, (d) ISO 22000 Food Safety Management Systems, (e) ISO 27001 Information Security Management Systems etc.,

\section{Conclusion}

The main advantage of having a truly integrated system is that there are elements of all Standards that are similar or the same. The common features include control of documents, Control of records, Training, competence and awareness, internal audit, Management review, Monitoring and measurement, Continuous improvement, Corrective and Preventive action. An IMS can therefore reduce the auditing time on site because some elements only need to be verified once rather than for each separate management system. By avoiding duplication of systems it leads to a more efficient management process. A culture and track record of integrated management systems is proof that the organisation is committed to enhancing performance while remaining cost effective, increasing employee and customer satisfaction, and facilitating continuous improvement.

\section{References}

[1]. Annex SL (normative) Proposals for management system standards.

[2]. ISO/CD 9001 Quality Management Systems - Requirements.

[3]. ISO/CD 14001 Environmental Management Systems - Requirements.

[4]. ISO/CD 18001 Occupational Health and Safety Management Systems - Requirements. 
[5]. ISO/CD 26000 Corporate Social Responsibility and guidance on social responsibility - Requirements.

[6]. ISO/CD 19600 Compliance Management Systems - Requirements.

[7]. ISO/CD 27001 Information Security Management Systems - Requirements.

[8]. ISO/CD 50001 Energy Management Systems - Requirements.

[9]. ISO/CD 22301 Business Continuity Management Systems - Requirements.

[10]. ISO/CD 20121 Event Sustainability Management Systems - Requirements.

[11]. ISO/CD 28000 Supply Chain Security Management Systems - Requirements.

[12]. ISO/CD 20000 IT Service Management Systems - Requirements.

[13]. ISO/CD 22000 Food Safety Management Systems - Requirements.

[14]. ISO/CD 31000 Risk Management Systems - Requirements.

[15]. ISO/CD 22400 Key Performance Indicators for manufacturing operation - Requirements. 